$45: 50$

〈原 著〉

患者，家族および医療従事者に対する「高齢者の終末期医療」についての意識調査

水川真二郎

要 約 目的: 近年, わが国では高齢者人口の急激な増加に伴い,「高齢者の終末期医療」に対する関心が高 まっている. しかし, 高齢者にとって「望ましい死」とは何か, 「高齢者の終末期医療」ではどのような医療 環境やケアを優先すべきかなど数多くの課題が残されている. この研究では, 高齢患者と家族および医師を 含めた医療従事者が,「高齢者の終末期」をどのように捉え,「高齢者の終末期医療」において何が最も重要な 要素であると認識しているのかについてアンケート調査を実施した，そして，これらの成績を解析すること により,「高齢者の終末期医療」における老年科医の役割について検討した．方法：対象は「高齢者の終末期 医療」に関するアンケート調査に同意の得られた高齢患者 148 名 (患者群), 患者の家族 76 名 (家族群), 医師 105 名 (医師群), 看護師 784 名（看護師群）および介護職員 193 名（介護職員群）である. 結果：“「高 齢者の終末期」とはどのような状態か”の問いに対して,「生命予後の危機」と解答したものは医師群, 看護 師群, 介護職員群でいずれも $70 \%$ 以上であった. しかし, 患者群と家族群ではそれぞれ $61 \%$ と $52 \%$ で, 医師群（75\%）と比較して少なかった．これに対して「日常生活動作の低下」と解答したものは, 患者群と 家族群ではそれぞれ $36 \%$ と $45 \%$ で, 医師群 $(23 \%)$, 看護師群 $(8 \%)$, 介護職員群 $(24 \%)$ よりも多かっ た.“高齢者の終末期医療」で重要な要素は何か”の問いに対しては,「鎮痛・苦痛除去」「「死に対する不安の 解除」「「友人や家族とのコミュニケーション」,「尊厳をもった扱い」の 4 つを最重要と回答したものがいずれ の群でも多かった $(>70 \%)$. 一方,「信条・習慣への配慮」は, 医師群 $(63.8 \%)$ と比較して患者群 (16.1\%), 家族群 (28.2\%) でいずれも少なかった.「在宅死」を重要な要素と回答したものは, 医師群 $(37.5 \%)$ と比 較して患者群 $(21.0 \%)$ と家族群（7.1\%) で少なかった. 結論：「高齢者の終末期医療」に対する捉え方や 考え方は，患者や家族あるいは同じ医療に携わるものでも，その立場や職種によって大きく異なっていた. 高齢者医療を専門とする老年科医は,「高齢者の終末期」に生じる様々な問題を全て医療の手法によって解決 しょうとはせずに,「高齢者の終末期医療」を患者や家族との共同作業であると捉え，共通の認識に基づいた 医療の実践に努力すべきであると考えられた。

Key words : 加齢, 終末期, QOL, 老年科医

（日老医誌 $2008 ； 45 ： 50-58$ )

\section{緒言}

1967 年, Cicely Saunders 医師が英国における最初の ホスピス (St. Christopher's Hospice) をロンドン郊外 に開設122) して以来, 終末期医療の問題は主に末期癌や HIV 感染症などの死が差し迫った状態にある患者を対 象に検討され, 疼痛の緩和 (palliation of pain) やイン フォームドコンセント (informed consent), 尊厳死 (death with dignity), 心のケア, 残された人生の質的 向上といった様々な課題について幅広い議論が積み重ね られてきだ ${ }^{3)}$. そ)の結果, 終末期医療に携わる医師は,

S. Mizukawa : 杏林大学医学部 高齢医学

受付日：2007.5.29, 採用日：2007.7.24
患者の自己決定や人格の尊厳を具現化し, 苦痛を和らげ 心の平安を与える緩和医療 (palliative medicine) の実

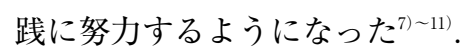

一方, 高齢者を対象とする医療は, 在宅, 施設, 病院 を問わず，壮年者のそれに比べて遥かに死に接近した医 療である. 多くの高齢者は, 基礎疾患に老化という不可 逆的現象が重なって, 少なからず要介護状態となり人生 の最終段階を迎える.しかし,「高齢者の終末期医療」に ついては, これまで十分な議論はおこなわれず，もっぱ ら医師の価値観や裁量によってその内容が決定されてき た ${ }^{12) ~ 15)}$.この背景には, 「高齢者の終末期医療」が, 生命 の問題だけでなく, 認知機能や日常生活動作の低下, あ るいは患者自身の生活が家族に大きく依存するあまりに 生じる経済的, 精神的負担といった, 壮年者にはみられ 
ない高齢者特有の要素を含み, 医学的知識だけでは決し て解決できない倫理的, 宗教的あるいは哲学的側面をも つためである.

このような多面的な要素をもつ高齢者の終末期医療に おいてこそ, 加齢による生体機能の変化や高齢者特有の 病態である老年症候群（geriatric syndrome）, 介護保 険制度や高齢者福祉といった高齢者医療全般に幅広い知 識をもつ老年科医の果たす役割は大きいといえよう.

そこでこの研究では，医療を受ける側の高齢患者やそ の家族と医療を提供する側の医師を含めた医療従事者 が,「高齢者の終末期」をどのように捉え,「高齢者の終末 期医療」において何が最も重要な要素であると認識し, どのような治療内容や医療環境を望んでいるのかをアン ケート調査した。 そして，これらの成績を解析すること により,「高齢者の終末期医療」における老年科医の役割 について検討した.

\section{対象と方法}

\section{1. 対象}

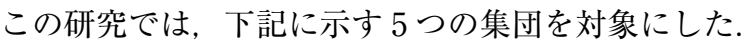

第一の集団は, 杏林大学医学部付属病院と東京都多摩 地区の一般病院抒よび老人保健施設に通院あるいは入院 （入所）中の高齢患者（65 歳以上）148名（患者群）で ある、第二の集団は，これらの患者を直接介護している 家族 76 名（家族群）である．第三の集団は，東京都多 摩地区の一般病院と老人保健施設に勤務する医師と東京 都武蔵野市医師会会員の 105 名（医師群）である．第四 と第五の集団は, 杏林大学医学部付属病院と東京都多摩 地区の一般病院抒よび老人保健施設に勤務する看護師 784 名（看護師群）と介護職員 193 名（介護職員群）で ある。

\section{2. アンケート調查の実施方法}

杏林大学医学部付属病院に入院中あるいは通院中の高 齢患者とその家族に対しては，直接面談して「高齢者の 終末期医療」に関するアンケート調査の目的と内容を説 明し，調查への協力を依頼した？その他の施設と団体に 対しては,「高齢者の終末期医療」に関するアンケート調 査の目的と内容を文書で説明し, 調査への協力を依頼し た.アンケート調査に同意の得られた患者, 家族, 施設, 団体には，それぞれ必要な部数のアンケート用紙を配付 し，郵送にて調查用紙を回収した。また，プライバシー を保護する目的で，アンケート用紙と返信用封筒はいず れも無記名とし，住所や電話番号などの個人の情報が特 定される可能性のある内容については，一切記入の「必 要なし」とした.
総数 1,500 部のアンケート用紙による調査依頼に対し て，1,329 部の回答を得たが, 記載不備により 23 部を除 外し, 残り 1,306 部（87.1\%）を解析対象とした.

3. 調查内容

この調查研究に用いた「高齢者の終末期医療」に関す るアンケート調査の内容を Table 1に示した. アンケー 卜調查の内容は, 下記に示す 2 つの項目から構成した.

すなわち,“「高齢者の終末期」とはどのような状態か” と“高齢者の終末期医療」に扔いて重要な要素は何か” の 2 項目である.

“「高齢者の終末期」とはどのような状態か”の項目で は，1）生命予後の危機，2）日常生活動作（activities of daily living; ADL) の低下，3）知的機能の低下（認知 症など）の 3 つの中から最も「高齢者の終末期」と考え られる状態を 1 つ選択していただいた。つぎに，日常生 活機能の低下と回答したものに対して, “どのような状態 を「高齢者の終末期」の始まりと考えるか”を，1）食 事全介助，2）排泄全介助，3）寝返りがうてないの 3 つ の選択肢の中から 1つを選んでいただいた。

“「高齢者の終末期医療」において重要な要素は何か” の項目では, 医療行為, 医療環境, 自然死・在宅死の 3 つの要素を中心に 5 段階評価で回答を得た。すなわち, 医療行為として「延命治療」,「死周期の蘇生療法」,「栄養 補充」,「輸血」,「鎮痛・苦痛除去」の 5 項目, 医療環境と して「死に対する不安からの解除」「友人や家族とのコ ミュニケーション」,「整容の充実」,「ADL の保持」,「個 室」,「家族が付き添うことができる」,「音楽・絵画・植 物」,「事前指示の確認」,「信条・習慣への配慮」,「尊厳を もって扱われること」の 10 項目, そして「自然死」と 「在宅死」の計 17 項目について, 最も重要 (5), 重要(4), やや重要 (3), あまり重要でない (2), 重要性が低い (1) の 5 段階で評価していただいた.

なお，この研究では,「高齢者の終末期医療」における 老年科医の役割について考察することを目的としたた め, 医師群で得られた成績を基準にして, 患者群, 家族 群，医師群，看護師群，介護職員群の 5 群間で比較検討 した. 調查成績の統計学的解析は, $\chi^{2}$ 乗検定を用いて, $\mathrm{p}<0.05$ 以下をもって統計学的有意とした．対象群の年 齢は平均值 \pm 標準偏差, 各質問に対する回答数は実数あ るいは百分率でそれぞれ表記した。“高齢者の終末期医 療」において重要な要素は何か”の 17 項目については, 各群において最重要と認識されている要素を明確にする ために，5段階評価の「最も重要（5)」の回答数を百分 率でそれぞれ表記した。 
Table 1 Contents of questionnaire

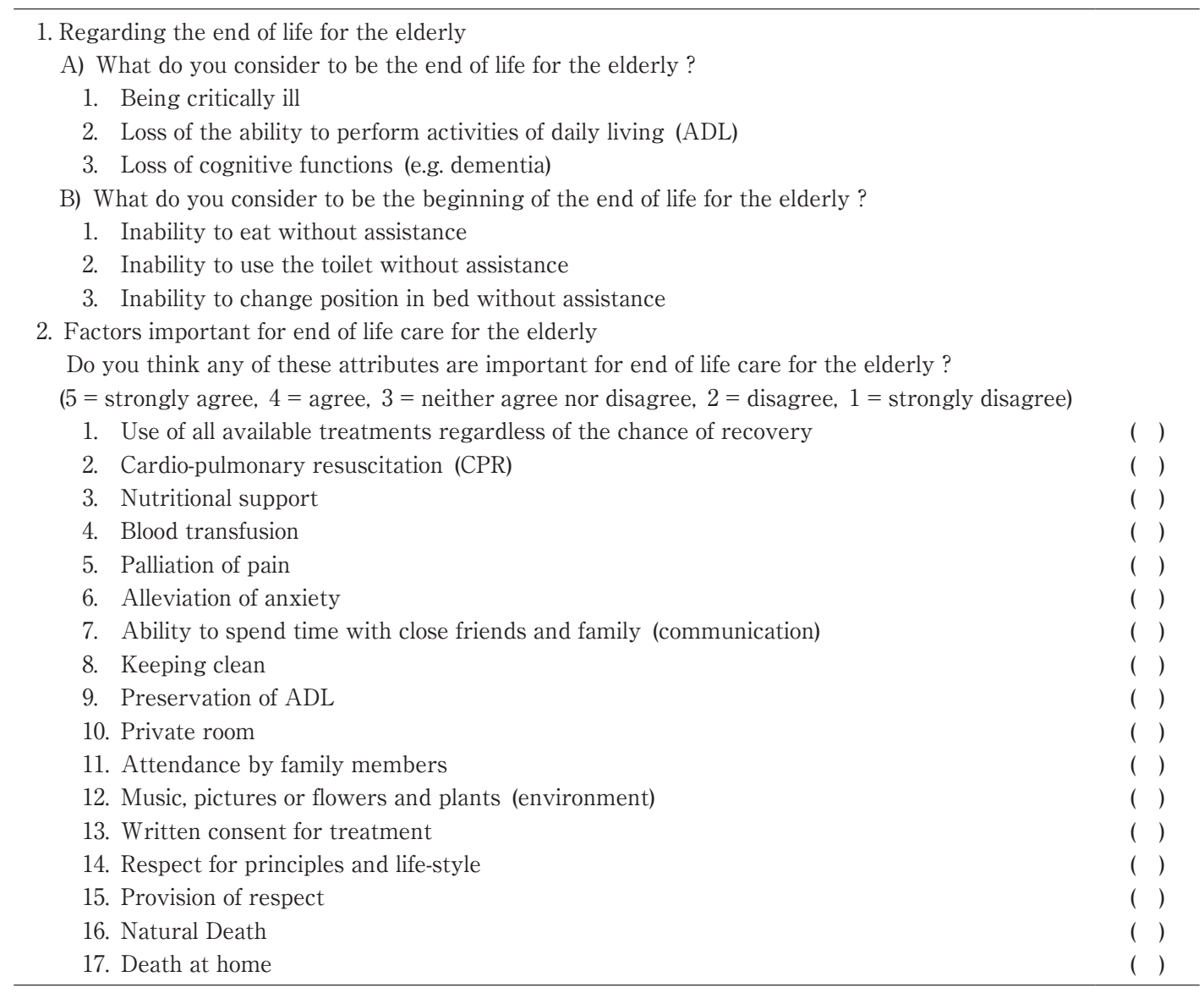

\section{成 績}

調査研究の成績は，1）調查対象例の背景，2）“「高齢 者の終末期」とはどのような状態か”についての調査成 績，3）“高齢者の終末期医療」において重要な要素は 何か”についての調査成績の順にそれぞれ記載した.

\section{1. 調查対象例の背景}

患者群と家族群の背景を Table 2 に，医師群，看護師 群，介護職員群の背景を Table 3にそれぞれ示した.

患者群の平均年齢は $78 \pm 9$ 歳で, 全体の $42 \%$ が介護 保険制度による介護サービスを受けていた。家族群の平 均年齢は $61 \pm 10$ 歳で，主な介護者の続柄は娘が $38 \%$ と 最も多く，次いで妻 $(26 \%)$, 嫁 $(16 \%)$ の順であった.

医師群，看護師群，介護職員群の平均年齢はそれぞれ $54 \pm 14$ 歳, $29 \pm 9$ 歳, $42 \pm 11$ 歳で, 専門職としての実 務期間の平均はそれぞれ 28 年， 8 年， 6 年であった。医 師群の専門領域では，内科を専門とするものが $48 \%$ で 最も多かった.「高齢者の終末期医療」に関する講義や実 習を受けた経験をもつものは，医師群で $5 \%$ であったの に対し, 看護師群と介護職員群ではそれぞれ $40 \%$ と
27\%であった.

2. “高齢者の終末期」とはどのような状態か”につ いての調査成績

“「高齢者の終末期」とはどのような状態か”の問いに 対する調查成績を Table 4に示した.

「生命予後の危機」と解答したものは，医師群，看護 師群，介護職員群で，いずれも $70 \%$ 以上であった，し かし，患者群と家族群ではそれぞれ $61 \%$ と $52 \%$ で，医 師群 $(75 \%)$ と比較して有意に少なかった $(\mathrm{p}<0.05, \mathrm{p}<$ 0.001)。これに対して「日常生活動作（ADL）の低下」 と回答したものは，患者群と家族群でそれぞれ $36 \%$ と $45 \%$ で, 医師群 $(23 \%)$ と比較して有意に多かった $(\mathrm{p}<$ $0.05, \mathrm{p}<0.01)$. 「知的機能の低下」と解答したものは,

いずれの群も少数であった.

つぎに, “「高齢者の終末期」とはどのような状態か”の 問いで「日常生活動作（ADL）の低下」と回答したも のに対して, “どのような状態を「高齢者の終末期」の始 まりと考えるか”を尋ねた成績が Table 5である。医師 群では「食事全介助」と回答したものが最も高頻度 $(52 \%)$ であったが，患者群では「排泄全介助」(56\%)，家族群 
では「排泄全介助」と「食事全介助」と回答したものが 多かった $(48 \%, 45 \%)$. また, 看護師群では「寝返り がうてない」(48\%), 介護職員群では「排泄全介助」と 「寝返りがうてない」と回答したものが多かった $(40 \%)$.

3. “高齢者の終末期医療」において重要な要素は何 か”についての調査成績

Table 6には,「高齢者の終末期医療」における医療行 為についての調查成績をまとめた、鎮痛・苦痛除去」を 最も重要な要素であると回答したものは, いずれの群で も高頻度（>70\%）であった.「死周期の蘇生療法」「「栄

Table 2 Demographics of survey participants (1)

\begin{tabular}{l|c|c}
\hline & Patients & $\begin{array}{c}\text { Family } \\
\text { members }\end{array}$ \\
\hline Number (n) & 148 & 76 \\
Male (n) & 44 & 11 \\
Female (n) & 104 & 65 \\
Average age (y. o.) & $78 \pm 9$ & $61 \pm 10$ \\
Public long term care insurance & & \\
service & $42 \%$ & - \\
Yes & $58 \%$ & - \\
No & & \\
Primary caregivers in the family & - & $26 \%$ \\
member & - & $16 \%$ \\
Wife (\%) & - & $38 \%$ \\
Daughter-in-law (\%) & - & $20 \%$ \\
Daughter (\%) & \\
Others (\%) &
\end{tabular}

養補充」,「輸血」を最重要と回答したものは, 医師群で はそれぞれ $4.3 \%, 6.0 \%, 1.1 \%$ であったのに対して， 患者群ではそれぞれ $8.3 \%, 11.7 \%, 8.9 \%$ でいずれの要 素も統計学的に有意ではないが医師群に比較して多い傾 向がみられた.

医療環境についての調查成績をまとめたのが Table 7 である.「死に対する不安の解除」,「友人や家族とのコ ミュニケーション」,「尊厳をもった扱い」の 3 つ要素は, いずれの群でも最重要と回答したものが大半を占めた

Table 3 Demographics of survey participants (2)

\begin{tabular}{l|c|c|c}
\hline & Physicians & Nurses & Caregivers \\
\hline Number (n) & 105 & 784 & 193 \\
Males (n) & 84 & 18 & 18 \\
$\quad$ Females (n) & 21 & 766 & 175 \\
Average age (y. o.) & $54 \pm 14$ & $29 \pm 9$ & $42 \pm 11$ \\
Professional career (y) & 28 & 8 & 6 \\
Expertise & & & \\
$\quad \begin{array}{l}\text { Internal medicine (\%) } \\
\text { Surgery (\%) }\end{array}$ & $48 \%$ & - & - \\
$\quad \begin{array}{l}\text { Gerontology (\%) } \\
\text { Others (\%) }\end{array}$ & $1 \%$ & - & - \\
$\begin{array}{l}\text { Have you had any kind } \\
\text { of education or practices }\end{array}$ & $44 \%$ & - & - \\
for end of life care for \\
the elderly?
\end{tabular}

Table 4 Regarding the end of life for the elderly

\begin{tabular}{l|c|c|c|c|c}
\hline & $\begin{array}{c}\text { Patients } \\
(\mathrm{n}=107)\end{array}$ & $\begin{array}{c}\text { Family } \\
\text { members }(\mathrm{n}=71)\end{array}$ & $\begin{array}{c}\text { Physicians } \\
(\mathrm{n}=104)\end{array}$ & $\begin{array}{c}\text { Nurses } \\
(\mathrm{n}=769)\end{array}$ & $\begin{array}{c}\text { Other } \\
\text { caregivers }(\mathrm{n}=180)\end{array}$ \\
\hline $\begin{array}{l}\text { Being critically ill } \\
\begin{array}{l}\text { Loss of the ability } \\
\text { to perform activi- } \\
\text { ties of daily living }\end{array}\end{array}$ & $39(61 \%)^{*}$ & $37(52 \%)^{* *}$ & $78(75 \%)$ & $702(91 \%) * * *$ & $132(73 \%)$ \\
$\begin{array}{l}\text { Loss of cognitive } \\
\text { functions }\end{array}$ & $3(3 \%)$ & $2(3 \%)$ & $2(2 \%)$ & $61(8 \%) * * *$ & $24 \%)$ \\
\hline
\end{tabular}

$*: \mathrm{p}<0.05, * *: \mathrm{p}<0.01,{ }^{* * *}: \mathrm{p}<0.001$ compared with physicians

Table 5 Regarding the beginning of the end of life for the elderly

\begin{tabular}{l|c|c|c|c|c}
\hline & $\begin{array}{c}\text { Patients } \\
(\mathrm{n}=34)\end{array}$ & $\begin{array}{c}\text { Family } \\
\text { members (n=29) }\end{array}$ & $\begin{array}{c}\text { Physicians } \\
(\mathrm{n}=23)\end{array}$ & $\begin{array}{c}\text { Nurses } \\
(\mathrm{n}=50)\end{array}$ & $\begin{array}{c}\text { Other } \\
\text { caregivers (n=40) }\end{array}$ \\
\hline $\begin{array}{l}\text { Inability to eat without as- } \\
\text { sistance }\end{array}$ & $12(35 \%)$ & $13(45 \%)$ & $12(52 \%)$ & $10(20 \%)^{* *}$ & $8(20 \%)^{* *}$ \\
$\begin{array}{l}\text { Inability to use the toilet } \\
\text { without assistance }\end{array}$ & $18(56 \%)$ & $14(48 \%)$ & $9(39 \%)$ & $16(32 \%)$ & $16(40 \%)$ \\
$\begin{array}{l}\text { Inability to change position } \\
\text { in bed without assistance }\end{array}$ & $4(12 \%)$ & $2(7 \%)$ & $2(9 \%)$ & $24(48 \%)^{* *}$ & $16(40 \%)^{*}$ \\
\hline
\end{tabular}

*: $p<0.05,{ }^{* *}: \mathrm{p}<0.01$ compared with physicians 
Table 6 Factors important for end of life care for the elderly (1)

\begin{tabular}{l|c|c|c|c|c}
\hline & $\begin{array}{c}\text { Patients } \\
(\mathrm{n}=70)\end{array}$ & $\begin{array}{c}\text { Family } \\
\text { members (n=50) }\end{array}$ & $\begin{array}{c}\text { Physicians } \\
(\mathrm{n}=79)\end{array}$ & $\begin{array}{c}\text { Nurses } \\
(\mathrm{n}=565)\end{array}$ & $\begin{array}{c}\text { Other } \\
\text { caregivers (n=124) }\end{array}$ \\
\hline $\begin{array}{l}\text { Use of all available treatments } \\
\text { regardless of the chance of } \\
\text { recovery }\end{array}$ & $5.2 \%$ & $7.8 \%$ & $4.0 \%$ & $5.5 \%$ & $4.3 \%$ \\
$\begin{array}{l}\text { Cardio-pulmonary } \\
\text { resuscitation }\end{array}$ & $8.3 \%$ & $9.7 \%$ & $4.3 \%$ & $8.1 \%$ & $5.4 \%$ \\
$\begin{array}{l}\text { Nutritional support } \\
\text { Blood transfusion }\end{array}$ & $11.7 \%$ & $7.0 \%$ & $6.0 \%$ & $15.1 \%$ & $21.7 \% * *$ \\
Palliation of pain & $8.9 \%$ & $7.5 \%$ & $1.1 \%$ & $4.7 \%$ & $7.3 \%$ \\
\hline
\end{tabular}

**: $\mathrm{p}<0.01$ compared with physicians

Table 7 Factors important for end of life care for the elderly (2)

\begin{tabular}{l|l|c|c|c|c}
\hline & $\begin{array}{c}\text { Patients } \\
(\mathrm{n}=70)\end{array}$ & $\begin{array}{c}\text { Family } \\
\text { members (n=50) }\end{array}$ & $\begin{array}{c}\text { Physicians } \\
(\mathrm{n}=79)\end{array}$ & $\begin{array}{c}\text { Nurses } \\
(\mathrm{n}=565)\end{array}$ & $\begin{array}{c}\text { Other } \\
\text { caregivers (n=124) }\end{array}$ \\
\hline $\begin{array}{l}\text { Alleviation of anxiety } \\
\begin{array}{l}\text { Ability to spend time with close } \\
\text { friends and family }\end{array}\end{array}$ & $71.4 \% *$ & $84.0 \%$ & $86.2 \%$ & $95.1 \% *$ & $89.4 \%$ \\
(communication) & $71.2 \% * * *$ & $74.5 \% * *$ & $93.2 \%$ & $97.3 \%$ & $94.1 \%$ \\
Keeping clean & $36.7 \%$ & $43.2 \%$ & $43.1 \%$ & $85.6 \% * * *$ & $65.8 \% * *$ \\
Preservation of ADL & $51.9 \%$ & $43.9 \%$ & $43.5 \%$ & $55.8 \% *$ & $29.6 \%$ \\
Private room & $31.7 \%$ & $16.1 \%$ & $28.0 \%$ & $25.2 \%$ & $16.0 \% *$ \\
Attendance by family members & $29.2 \%$ & $12.0 \% * *$ & $37.0 \%$ & $54.4 \% * *$ & $35.4 \%$ \\
Music, pictures or flowers and & $14.3 \%$ & $12.7 \%$ & $11.8 \%$ & $38.9 \% * * *$ & $17.5 \%$ \\
plants (environment) & & & & & \\
Written consent for treatment & $53.7 \%$ & $47.9 \%$ & $63.1 \%$ & $79.6 \% * *$ & $66.0 \%$ \\
Respect of principles and life-style & $16.1 \% * * *$ & $28.2 \% * * *$ & $63.8 \%$ & $77.5 \% * *$ & $59.4 \%$ \\
Provision of respect & $86.5 \%$ & $98.0 \%$ & $94.7 \%$ & $97.3 \%$ & $97.9 \%$ \\
\hline
\end{tabular}

$*: \mathrm{p}<0.05, * *: \mathrm{p}<0.01, * * *: \mathrm{p}<0.001$ compared with physicians

(>70\%).一方,「整容の充害」を最重要と回答したもの は，看護師群と介護職員群でそれぞれ $85.6 \%$ と $65.8 \%$ であったのに対し，患者群では $36.7 \%$ と少数であった. $\lceil\mathrm{ADL} の$ 保持」と「個室」を重要な要素とする解答は, 医師群, 患者群, 家族群で有意な差はみられなかった.「家 族が付き添うことができる」を最重要と回答したものは, 医師群と比較し家族群で有意に少なかった（37.0\% vs. $12.0 \%, \mathrm{p}<0.01)$.「音楽・絵画・植物」と「事前指示の 確認」は, 医師群と比較し看護師群で有意に高頻度であっ たが $(11.8 \%$ vs $38.9 \%, \mathrm{p}<0.001,63.1 \%$ vs $79.6 \%, \mathrm{p}<$ $0.01)$, 患者群, 家族群とは有意な差はみられなかった。 「信条・習慣への配慮」は, 医師群と比較して, 患者群 と家族群でいずれも有意に少なかった (63.8\% vs 16.1\%， $\mathrm{p}<0.001,63.8 \%$ vs $28.2 \%, \mathrm{p}<0.001)$.

Table 8には, 「自然死」と「在宅死」についての調査 成績をまとめた.「自然死」は，いずれの群も半数以上が 重要な要素であると回答した。しかし,「在宅死」を最重 要と回答したものは, 医師群と比較して患者群と家族群 で有意に少なかった $(37.5 \%$ vs $21.0 \%, \mathrm{p}<0.05,37.5 \%$ vs $7.1 \%, \quad \mathrm{p}<0.001)$.

\section{考案}

この調查研究によって, 医療を受ける側の患者や家族 と医療を提供する側の医師を含めた医療従事者の間に,

「高齢者の終末期」に対する捉え方や「高齢者の終末期 医療」に扔いて重要と思われる要素の認識に大きな違い がみられることが明らかになった。また，同じ医療に携 わるものでも，その職種や立場によって捉え方に差のあ ることも明らかになった。

すなわち,「高齢者の終末期」と考える状態については, いずれの群も半数以上が「生命予後の危機」と回答した. しかしその一方で, 高齢者に特有の病態である「日常生 活動作の低下」も「高齢者の終末期」であると回答した ものは, 医師群と比較して患者群と家族群で有意に多 かった。これは，医師が医学教育や臨床実習を通して生 死の問題こそが医療における最重要事項であると教えら れ，延命や治療を目的とした現代医療の実践に力を注い できたために，生活の質や残された人生の過ごし方を重 
Table 8 Factors important for end of life care for the elderly (3)

\begin{tabular}{l|c|c|c|c|c}
\hline & $\begin{array}{c}\text { Patients } \\
(\mathrm{n}=70)\end{array}$ & $\begin{array}{c}\text { Family } \\
\text { members }(\mathrm{n}=50)\end{array}$ & $\begin{array}{c}\text { Physicians } \\
(\mathrm{n}=79)\end{array}$ & $\begin{array}{c}\text { Nurses } \\
(\mathrm{n}=565)\end{array}$ & $\begin{array}{c}\text { Other } \\
\text { caregiver }(\mathrm{n}=124)\end{array}$ \\
\hline Natural Death & $63.2 \%$ & $58.0 \%$ & $54.1 \%$ & $54.0 \%$ & $66.0 \%$ \\
Death at home & $21.0 \% *$ & $7.1 \% * * *$ & $37.5 \%$ & $50.1 \% *$ & $34.5 \%$ \\
\hline
\end{tabular}

$*: \mathrm{p}<0.05, * *: \mathrm{p}<0.01, * * *: \mathrm{p}<0.001$ compared with physicians

視する患者や家族と「高齢者の終末期」に対する認識に 差が生じている可能性が示唆された.

厚生労働省「国民生活基礎調査」によると，現在わが 国にはおよそ356,000 人の「寝たきり」患者が存在する と推定されている。 そして，その原因の第一位は脳血管 障害 $(36.7 \%)$ で，第二位は加齢による衰弱 (13.6\%) で ある ${ }^{16)}$ ．高齢者や高齢者を長期にわたり介護する家族の 中には，基礎疾患が何であれ日常生活動作が徐々に低下 し「寝たきり」に陥るこの過程も,「生命予後の危機」と 同様に「高齢者の終末期」と捉えているものが多数存在 すると考えられた。

“どのような状態を「高齢者の終末期」の始まりと考 えるか”の項目では, 職種によって回答に差がみられた. 医療は，医師と看護師や介護職員などの医療従事者が揖 こなう共同作業である。しかし，同じ医療に携わるもの でも，臨床現場における業務内容や患者を観察する視点 の違いによって,「高齢者の終末期」の始まりに対する捉 え方に違いのあることが明らかになった．高齢者を対象 とする医療では，点滴や投薬内容の指示といった医師に よる治療よりも，むしろ裖瘡予防のための体位変換や食 事介助などの看護師や介護職員が主体となっておこなう ケアが重要である場合が多い。したがって,「高齢者の終 末期医療」に携わる医師は，職種や立場の違いを越えて 医療従事者が「高齢者の終末期」に対する共通の認識を 構築するよう中心となり努力する必要があると思われ た.

“「高齢者の終末期医療」において重要な要素は何か” の項目では，われわれが日常の臨床で重要と実感してい る要素を, 医療行為, 医療環境, 自然死・在宅死の 3 つ に分けて 17 の項目として列挙し, 回答を求めた.

「高齢者の終末期医療」の医療行為では, 「鎮痛・苦痛 除去」を最も重要な要素であると回答したものが, いず れの群でも多かったここの結果は，これまでの末期癌や エイズ患者を対象にした緩和ケア領域における調査研究 の成績と同様であり ${ }^{17) ~ 19)}$, 「高齢者の終末期医療」におい ても疼痛や苦痛に対する治療が最も優先すべき医療行為 であることが確認できた.

一方, この調查研究の成績によって,「高齢者の終末期
医療」の課題も明らかになった。すなわち,「死周期の蘇 生療法」「栄養補充」「「輸血」を最重要と回答したものは, 統計学的に有意ではなかったが, 医師群と比較して患者 群や家族群で多い傾向がみられた。このことは，医師が 基礎疾患の重症度や病状経過などの医学的観点からみて 「必要なし」と判断した医療行為であっても, 患者や家 族の中には，それを望むものが少なからず存在すること を示している.

「高齢者の終末期医療」の問題点として，しばしば医 療が過剩になることや，これとは対照的に高齢だという 理由で過小になることが指摘されているる2120). この点は, 今後検討すべき重要な課題といえるが,「高齢者の終末期 医療」においては，医学的あるいは経験的観測からのみ で医療の内容を決定するのではなく，患者や家族の意向 を十分に波み取りその内容を判断する必要があると思わ れた。

「高齢者の終末期医療」の医療環境についてみると,「死 に対する不安の解除」,「コミュニケーション」,「尊厳を もった扱い」の 3 つの要素は, いずれの群でも大半が最 重要と回答した。しかし,「整容」や「信条・習慣への配 慮」など, 日頃から医療従事者が重要と考えている要素 の中には, 患者や家族があまり重要視していない要素も 含まれていることが明らかになった.

2000 年 4 月よりわが国では新しく介護保険法が施行 され, 在宅ケアや訪問看護システムの充実が図られてき た.このため，われわれは「自然死」や「在宅死」に， 圧倒的な支持が得られるものと予想した。 しかし，この 調查研究の成績では, 患者や家族は「自然死」を望む一 方で，医師が思うほどには「在宅死」を望んでいなかっ た.

この原因としては，1）この調査研究が比較的都市部 に在住する高齢者や家族を対象にしたために，住宅環境 や共働きなどの生活環境が在宅医療の障害になっている こと，2）家族の中には，実際に病状が悪化し死に直面 した場合，どのように対処すべきか不安に思うものが少 なくないこと，3）患者自身も家族に精神的あるいは肉 体的負担をかけたくないと思っていることなどが考えら れた，事実，これまでの癌患者を対象とした調查研究に 
おいても,「在宅死」を望むもが少ないことが報告されて いる ${ }^{18)}$.このように, 医師からみれば望ましいと思える 自宅での死であっても, 患者や家族に強要することは慎 むべき行為であると思われた。

「高齢者の終末期医療」に扔いて, 患者, 家族, 医療 従事者は, それぞれに重要な役割を担っている.しかし， この調查研究の成績にみるように,「高齢者の終末期医 療」で重要と考える要素には，それぞれの立場によって 捉え方に大きな隔たりがみられた。こうした観点からみ ると，医師を含めた医療従事者は，「高齢者の終末期」に 生じる様々な問題を, 全て医療の手法によって解決しょ うとはせずに,「高齢者の終末期医療」を患者や家族との 共同作業と捉え, 医療の進め方やケアの方法について十 分に話し合い，共通の認識に基づいた医療の実践に努力 すべきであると考えられた，そして，刻々と変化する病 状に対しておこなわれる医療やケアの内容が，共通の認 識に基づいたものであるかを常に見直すことが必要であ ると思われた。

この調查研究の成績には, いくつかの限界と制限がみ られる。その第一は, “高齢者の終末期」とはどのよう な状態か”と“どのような状態を「高齢者の終末期」の 始まりと考えるか”の問いにおいて，それぞれ 3 つの限 られた選択肢の中から回答を求めた点である.すなわち, 「高齢者の終末期」として, 生命予後の危機, 日常生活 動作の低下，知的機能の低下の 3 つを，その始まりとし て, 食事全介助, 排泄全介助, 寝返りがうてないの 3 つ をそれぞれ選択肢とした。しかし、「高齢者の終末期」の 病態は多様であり，一概にこれらの選択肢に当てはめて 回答することは困難である. 事実, “どのような状態を「高 齢者の終末期」の始まりと考えるか”の問いに対して回 答のなかったものが, 少数ではあるが各群でみられ，選 択肢の設定方法が成績に影響を与えた可能性が考えられ る. 第二は，患者群を在宅と施設入所（入院）に分けて 調査をおこなわなかった点である。高齢者の終末期医 療」の要素の中でも，とくに「自然死」の捉え方や「在 宅死」に対する考え方には，それぞれの高齢者が在宅で あるか，あるいは入所（入院）中であるかといった現在 の生活場所が大きな影響を与える。このため，患者群を 在宅と施設入所（入院）に分けて調査をおこなう必要が あったと思われる．第三は，この調査研究が主に東京都 多摩地区の限られた地域に在住する高齢患者とその家族 を対象にした点である.「在宅死」についての考察で述べ たように，人それぞれが考える最適な「高齢者の終末期 医療」には，生活の基盤である住宅環境や家族構成，経 済的状況などの様々な要因が大きく影響する.このため,
この調査研究の成績を, 一般化するには注意が必要であ る. 第四は, 看護師群の平均年齢が比較的若い点である. 「高齢者の終末期」という死生観や人生観をも含む課題 に対しては，当然，各世代で異なる意見や見方があって しかるべきである。しかし，こうした多様な集団を対象 にした調査研究を積み重ねることが, 現状の「高齢者の 終末期医療」の問題点を明らかにし，ょり良い医療の提 供に結びつくと思われる.

米国老年医学会は,「高齢者の終末期医療」に関して「立 場表明」を扢こなっている ${ }^{21)}$.この中には, 終末期医療 はチーム医療であること，患者と家族を一体にしてケア すること，患者の訴え中心のケアを抢こなうことなどの 内容が謳われている．わが国においても，2001年に日 本老年医学会が「高齢者の終末期の医療㧍よびケア」に ついて，高齢であることや自立能力が低下していること などの理由により，適切な医療およびケアが受けられな い差別があってはならないことや，患者個々の価值観や 思想，信仰を十分に尊重することなどの内容を含んだ 13 項目からなる「立場表明」をおこなっている ${ }^{22233}$. 老年 科医は，こうした新たな取り組みに積極的に関わり，高 齢者が最後まで人間らしく生きることができるような終 末期医療の実現に努力すべきである.

謝辞：この調査研究を実施するにあたり，アンケート 調査に協力いただいた各施設の関倸者の皆様に深謝致し ます。

\section{協力施設}

杏林大学医学部 付属病院

東京都武蔵野市 医師会

医療法人社団慶成会 青梅慶友病院

医療法人財団紘友会 三鷹病院

医療法人財団慈生会 野村病院

三鷹市老人保険施設 はなかいどう

三鷹市老人保険施設 太郎

三鷹市老人保険施設 花水木

最後に稿を終えるにあたり，ご指導，ご校閲を賜りま した杏林大学医学部高齢医学主任教授 鳥羽研二教授に 深甚なる謝意を表します。また終始ご助言をいただきま した大荷満生准教授ならびにご協力をいただきました 末光有美医師に心から感謝を表します。

な押，この論文の内容の一部は，第 44 回日本老年医 学会学術集会「シンポジウムI：介護保険における老年 科医の役割」(2002 年, 東京), The $7^{\text {th }}$ Asia/Oceania Regional Congress of Gerontology (2003, Tokyo) で要旨 を発表したことを付記します。 


\section{文献}

1) Bennahum D: The historical development of hospice and palliative care, In: Hospice and palliative care, Sheehan D, Forman W (eds), Sudbury MA, 1996, p1-10.

2）柏木哲夫：ホスピスケアと緩和医療学 (背景と歴史). 緩和医療学 (Palliative Medicine) (日本緩和医療学会監 修), 三輪書店, 東京, 1997, p10-15.

3) The SUPPORT, Principal Investigators: A controlled trial to improve care for seriously ill hospitalized patients. The study to understand prognoses and preferences for outcomes and risks of treatments (SUPPORT). JAMA 1995; 274: 1591-1598.

4) Christakis NA, Escarce JJ: Survival of medicare prtients after enrollment in hospice program. N Engl J Med 1996; 335: 172-178.

5) Peretti-Watel P, Bendiane MK, Galinier A, Lapiana JM, Favre R, Pegliasco H, et al.: South-Eastern France Palliative Care Group: Opinions toward pain management and palliative care: comparison between HIV specialists and oncologists. AIDS Care 2004; 16: 619-627.

6) Kutzen HS: Integration of palliative care into primary care for human immunodeficiency virus-infected patients. Am J Med Sci 2004; 328: 37-47.

7) Expert Working Group of the Research Network of the European Association for Palliative Care: Morphine and alternative opioids in cancer pain. Br J Cancer 2001; 84: 597-593.

8) Wolfe J, Grier HE, Klar N, Levin SB, Ellenbogen JM, Salem-Schatz S, et al: Symptoms and suffering at the end of life in children with cancer. N Engl J Med 2000; 342: 326-333.

9) McCarthy EP, Phillips RS, Zhong Z, Drews RE, Lynn J: Dying with cancer: patients' function, symptoms, and care preferences as death approaches. J Am Geriatr Soc 2000; 48 (S5): S110-121.

10) Burstein HJ, Winer EP: Primary care for survivors of breast cancer. N Engl J Med 2000; 343: 1086-1094.

11）中川恵一, 岩瀬 哲, 村上 忠, 斉藤雄一郎, 佐藤嘉代子, 梅内美保子ほか：21 世紀の緩和医療. 日老医誌 2004; 41: 16-22.

12）村井淳志：高齢者の終末期医療. 日老医誌 2000; 37: 175-181.

13）中原賢一：医療者側から見た終末期医療：一般人からの との対比. 日老医誌 2004; 41:39-41.

14）平川仁尚, 益田雄一郎, 木俣貴哉, 植村和正, 暮谷雅文, 井口昭久: 緩和医療の行われていない療養型病床群 2 施 設における痴呆性高齢者の終末期医療に関する研究. 日 老医誌 2004; 41: 99-104.

15）萬谷直樹, 小暮敏明, 伊藤克彦, 坂本浩之助, 高玉真光, 田村遵一：終末期高齢者の医療に関する医師と看護師の 意識調査. 日老医雑 2003; 40: 504-508.

16）国民衛生の動向. 財団法人厚生統計協会, 第 50 巻 9 号 2003.

17) Hanson LC, Danis M, Garrett J: What is wrong with endof-life care? Opinions of bereaved family members. J Am Geriatr Soc 1997; 45: 1339-1344.

18) Singer PA, Martin DK, Kelner M: Quality end-of-life care. JAMA 1999; 281: 163-168.

19) Steinhauser KE, Christakis NA, Clipp EC, McNeilly M, McIntyre L, Tulsky JA: Factors considered important at the end of life by patients, family, physicians, and other care providers. JAMA 2000; 284: 2476-2482.

20) Morrison RS, Meier DE, Cassel CK: When too much is too little. N Engl J Med 1996; 335: 1755-1759.

21) American Geriatric Society Ethics Committee: The care of dying patients: A position statement from the American Geriatric Society. J Am Geriatr Soc 1995; 43: 577-578.

22）社団法人日本老年医学会：「高齢者の終末期の医療およ びケア」に関する日本老年医学会の「立場表明」. 日老 医誌 2001; 38: 582-586.

23）植村和正：「高齢者の終末期の医療およびケア」に関す る日本老年医学会の「立場表明」. 日老医誌 2004; 41: 4547. 


\title{
A survey on the view of end-of-life care in the elderly -A comparison among elderly patients, family members. physicians, nurses, and other caregivers-
}

\author{
Shinjirou Mizukawa
}

\section{Abstract}

Aim: The purpose of this study was to investigate the role of geriatric physicians in end-of-life care through surveying elderly patients, their families, and health-care providers including physicians, nurses, and other caregivers, in order to determine what comprises good end-of-life care.

Methods: The survey respondents comprised 148 elderly patients, 76 members of their families, 105 physicians, 784 nurses, and 193 other caregivers. The survey asked respondents to rate the importance of (a) indicators of end-of-life in the elderly and (b) 17 aspects of quality of end-of-life care.

Results: With respect to indicators of end-of-life in the elderly, a patient being consistently critically ill was rated highly by all health-care providers ( $>70 \%$ responded that this indicated end-of-life). Being unable to perform the activities of daily life was considered an indicator of end-of-life by $36 \%$ of patients and $45 \%$ of their family members, but only by $23 \%$ of physicians, $8 \%$ of nurses, and $24 \%$ of other caregivers. For quality of end-of-life care, four items were rated as being important by all groups ( $>70 \%$ in each group): palliation of pain, freedom from anxiety regarding death, ability to spend time with close friends or family, and being respected. However, respecting the patient's principles and lifestyle was thought to be less important by patients $(16.1 \%)$ and family members $(28.2 \%)$ than it was by physicians $(63.8 \%)$. Death at home was also thought to be less important by patients $(21.0 \%)$ and family members $(7.1 \%)$ than by physicians $(37.5 \%)$.

Conclusion: Elderly patients and their families have different views from their health-care providers on matters related to good end-of-life care. Geriatric physicians should pay attention to not only the care of patients' physical needs, but also other needs of the patients and their families.

Key words: Aging, Terminal care, Quality of Life, Geriatric physicians

(Nippon Ronen Igakkai Zasshi 2008; 45: 50-58)

Department of Gerontology, Kyorin University School of Medicine 